\title{
Development without Human Resource Development (HRD): Analysis of HRD Policy of Pakistan
}

\author{
Muhammad Mujtaba ${ }^{1^{*}}$--- Sadaf Jamal ${ }^{2}$--- Yaseen Shaikh ${ }^{3}$ \\ ${ }^{1,2}$ PhD-Management Sciences, SZABIST, Karachi, Pakistan \\ Email:smmujtaba14@gmail.com \\ ${ }^{3}$ MS-Project Management, MUISTD,MUET, Jamshoro, Pakisatan
}

\begin{abstract}
The purpose of this study is to understand the importance of Human Resource Development (HRD) in context of economic development of Pakistan and to assess that at what level HRD Policy of the state is effectively aligned with development of country. The qualitative approach is used in this study by applying triangulation method to collect data from different dimensions for same phenomenon by using phenomenology and focus group methodologies to reach in-depth understanding of matter through participants lived experience and opinions. Unstructured interviews were conducted from the representatives of the concerned government organizations and policy experts of Pakistan to collect primary data. The findings of research explain that the HRD Policy of Pakistan is not aligned with its vision of economic development and achieving the objects of the vision is unrealistic and inconsistent. This paper is useful for policy makers, investors and HR specialists to understand the importance of HRD in economic development of country.
\end{abstract}

Keywords: Development, Human resource development (HRD) policy, Public policy

Licensed: This work is licensed under a Creative Commons Attribution 4.o License.

Funding: This study received no specific financial support.

Competing Interests: The authors declare that they have no competing interests.

\section{Introduction}

Human excellence is one of primary and leading determinant to convert the vision into reality. The regular investment on the Human Resource Development (HRD) is nucleus reason behind the continuous success of leading firms. Quality of available human resource is not only support to domestic investors but also attract the attention of foreign investors for the development of country. It is key ingredient of strategic policy of firm towards its profit which ultimately helps in economic growth of the country. Human resource is acknowledged as single imperative strategic resource behind the success of fast economic growth of Singapore (Osman-Gani, 2004) and Singapore workers are recognized as best workers of the world in productivity and innovation (Standards, Productivity and Innovation Board, 2003).

According to Clarke and Gholamshahi (2018) the initial point of every development in $21^{\text {st }}$ century is focused on innovation, that can only be achieved through people, the innovation is not a government, not a business, not an institution but the people who work inside the these systems, where state responsibility is to develop and implement the effective public policy whereas as function of institutions is to prepare those kind talent to run the operations according to national public policy of that particular state. Recent past history of east Asia exhibit that a number of countries had dramatically improved their economic growth through effective HRD policy and invested huge amount on development of human skills. Astonishing economic growth of Asian tigers (i.e. Singapore, Honk Kong, Taiwan and South Korea) was mainly based on governments' concentration and huge investment on HRD (Tilak, 2002).

The accomplishment of every public policy is dependent on HRD Policy that means availability of human knowledge and skills in the country to implement the all public policies. In this regard, the careful attention of 
policy makers is inevitable and they need to think across and think ahead before hallmark the HRD policy of state because incompetence and careless attitude in designing of HRD policy will ultimately affect the economic targets. The capability of country to compete in at global platform is mainly depend on value addition and low cost of product through human knowledge and skills (Reich, 1991). International Institute of Management Development (1995) it is necessary for state to create competitive business environment in country through formulating effective public policy on macro and micro level with special focus on research work and develop knowledge and skilful human society. HRD Policy should be focused to create valuable human force for state through providing quality of education and new training to people towards development of required skills (Yussif and Ismail, 2002).

In context of Pakistan, according to International Labor Organization, (2016) the Pakistan has world's $9^{\text {th }}$ largest labor force, which is great potential for country to easily compete in global economy in every field with the support of designing and implement of effective HRD Policy. Quality as well as quantity of professionals (i.e. having managerial, technical and computer knowledge) are core drivers to run country's economy on fast track (Afza and Nazir, 2007). According to Pakistan Vision-2025, the Pakistan will be the Asian Tiger in 2025 and counted in the list of top ten economies of the world in 2047. The central pillar of this vision was based on development of Human and Social Capital (i.e. knowledge and skill) of the country as exhibited at Figure 1.1.

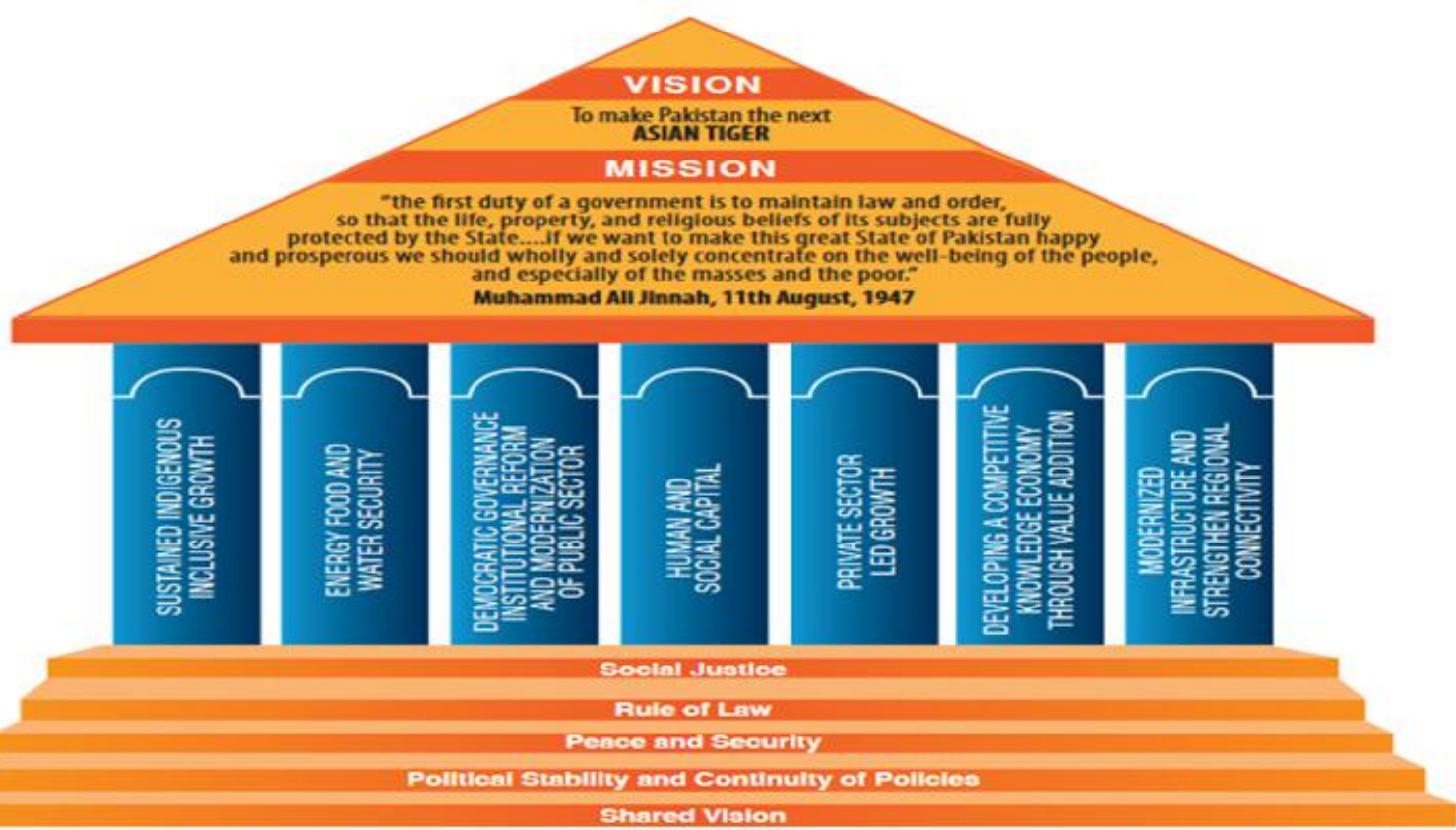

Source: Planning Commission Report (2015)

Figure-1.1. Pakistan Vision 2025

The vision was designed on seven pillars and among seven pillars, two (i.e. Human, Social Capital and Developing Competitive Knowledge Economy-Through Value Addition) are directly linked with HRD Policy and very essential for success of all development projects of vision-2025. But the existing HRD policy of Pakistan is complex as well as irrational and there is no consistency within and with other public polices pertain to development of country. The public policy makers of Pakistan have failed to understand the phenomenon and value of HRD (Afza and Nazir, 2007).

\subsection{Research Problem}

According to Global Human Capital Report (2017) the Pakistan's ranking in human resource development is in critical condition, and it has decreased from 2016 to 2017 as exhibit in at Table 1.

Table-1. Pakistan Ranking in list of Global Human Resource Development

\begin{tabular}{l|l|l|l}
\hline Year & Pakistan Number & Total Countries in Ranking & Score \\
\hline 2016 & 118 & 130 & 53.10 \\
\hline 2017 & 125 & 130 & 46.34 \\
\hline Source: The Global Human Capital Report, (2016); (2017).
\end{tabular}

According to Asrar-ul-Huq, (2015) there is great need to realign the HRD policy of Pakistan with its economic targets, so that development projects can be achieved in true spirit towards economic prosperity in country. Further, the regular advancements in information technology have created challenges for policymakers to realign their policy every time and develop their human resource accordingly (Tabassum, 2015). To retain skilled human resource, the organization needs to prepare comprehensive plan of HRD Policy 
before benchmark the strategic goals. HRD policy is varied form organization to organization but every HRD Policy is directly or indirectly related state's HRD Policy. The existing state HRD Policy of Pakistan is so complex and unrealistic. Due to existing system of human resource development of Pakistan, almost every development project has failed to achieve its objectives and has taken the country from bad to worst ranking position at world economic forum. Human Resource development is key factor for Pakistan to understand and handle with globalization phenomenon (Afza and Nazir, 2007). The focus of this study is giving the understanding to public policy makers of Pakistan to accept the realities of human development so that they should make complete and effective HRD policy for enrichment in economic competitiveness of country. Human Knowledge and skills are key instruments of nation to compete in globalization (Thurow, 1994).

\section{Literature Review}

According to United Nations Report (1991) the HRD Policies and activities support to acquisition of human knowledge, skills and attitude that bring mutual benefits for an individual and a business, and at larger for society. These policies are mostly developed macro level and micro level, macro level the policy need to focus on well being of nation (i.e. knowledge, skills, attitude, health) which helps in economic planning and it controls inflammation among citizen, whereas at micro level it is concerned with development of organization and individual (Latif, Nazar, Khan and Shaikh, 2011). The policies of advanced countries of world are committed to enhance human resource in digital epoch to achieve their economic targets, the prime challenge of these countries is not technology but the development of human capital (Clarke and Gholamshahi, 2018). Asia Pacific economies are in straight competition with Europe, United States and Japan in context of attainment of knowledge and skills to achieve their economic development (Dunning, 2006; Porter, 1990).

The main capacity of state to prepare effective public policy is based on knowledge and skills of policy makers and for execution of the public policy the state again required desired knowledge and skill of its people; development of any public policy without alignment or having data of available knowledge and skill in the country is the failure of policy as well as wastage of resources; one of the main reason behind the failure of public policy in non-developed countries is incompetency of policy makers to formulate effective public policy, the policy makers don't have requite data, knowledge and skill for preparation of public policy; they use traditional bureaucratic approach in $21^{\text {st }}$ Century to compete with developed countries which instead of taking them five year ahead but taking ten year back them than current status (United Nations, 2005).

Singapore's HRD policy has contributed a major role in national policy of country along with constant and adjustment of HRD Policy in consonance with other sub national polices, this country don't have any natural resource except port and having very small land but due to expertise in human resource, the Singapore is one of most developed country of Asia in these days, the uniqueness of Singapore success in globalization is grounded on strong foundation of human expertise and its huge continuous investment on human by implementing systematic policy of HRD Policy (Osman-Gani, 2004). National HRD Policy infrastructure or system of Singapore is divided in two sub systems namely Tripartite and multi departmental under one umbrella-Main System, firstly, the tripartite approach (sub system) is consist of the cooperation of government, employers and unions, whereas the second approach of multi departmental is based on the involvement of all government department and agencies under one umbrella (Ministry of Manpower, 2003). In Tripartite System, the government provides various skill trainings (align with national policy objectives) to its citizens, motivate and finance to employees to enhance their skills and encourage the employers to improve the existing skill of their employees, the fund for this program generated through government budget and contribution of employers who pay $2 \$$ every month to government and in return the government provide $90 \%$ discount in training programs of employees, through this system the employers happily send their employees for different trainings at very minimum price, and ultimately, this system increase the HRD of country, in addition to this, the government is operating number of different project under the Council of Tripartite Institution such as lifelong training school to give skill training to everyone at every stage of life, latest trainings to unemployed citizens so that they can reskill themselves to meet the job vacancies requirement of different firms and other various program under the centralized command and authority (Ministry of Manpower, 2003; Skills Development Fund, 2003).

Whereas in Multi departmental (sub system) in national polices for HRD Policy, the Singapore government has created a proper network of collaboration among all departments, in which every department share its required skills or human resource for its future development projects at central level, then the concerned government authority of HRD department gives the timeline or period in which the requisite human resource will be available in Singapore's labor market for particular project, after getting confirmation of date of availability of human resource in labor market then every department of state the hallmark its policy separately. Example, before 1998, the information regarding human resource needs of nation (all departments) collected by the EDB- Economic Development Board and submitted to CPTE- Council for Professional and Technical Education Singapore for its consideration, and then concerned agencies of HRD provide the timeframe to meet the targets of development of required human capital in the country. Presently, the Ministry of Manpower (MOM) is responsible to develop and implement the national human resource development policy; the existing strategic plan of HRD plan is designed by the MOM with the vision to make Singapore hub of talent capital with a systematic and constant enhancing knowledge and skills (Education 
system and HRD strategies are strongly linked and integrated with each other) of employees (Osman-Gani, 2004).

Pakistan economy is very weak to compete in world level but it has great potential to compete in global trade war through the development of human resource (Afza and Nazir, 2007). According to Planning Commission (2005) the main obstruction in development of human resource is the disparities and inconsistency of HRD Policy with the other public policies, consequently, these is huge gap and mismatch among education, training and skill programs.(Afza and Nazir, 2007). According to Clarke and Gholamshahi (2018) Majority of Asian countries national public policy is primarily supported by HRD Policy which provides the human capital to achieve the main targets of economic development, these countries are spending a huge amount of money on education, trainings and skills programs in as systematic way to train and polish their people to fulfil the future needs of different projects in their countries (Such as Hong Kong, China, India, Taiwan and others). Whereas, the Pakistan national policy for economic development is completely disconnected with HRD Policy, even there is no coherence within departments which are working on development of human resource of Pakistan. The existing HRD Policy government of Pakistan is so complex and unrealistic structured as exhibited in Figure 2.1.

\section{Human Resource Development (Palzistam)}

\begin{tabular}{|c|c|}
\hline Federal Level & Provincial Level \\
\hline Planning \& Development & Planning \& Development \\
\hline $\begin{array}{c}\text { Ministry of Labor, Manpower, } \\
\text { and Overseas Pakistanis }\end{array}$ & $\begin{array}{l}\text { Labor and Human Resource } \\
\text { Develonment Departments }\end{array}$ \\
\hline $\begin{array}{l}\text { National Commission for } \\
\text { Human Develonment (NCHD) }\end{array}$ & $\begin{array}{l}\text { Technical Education and } \\
\text { Vocational Training Authorities }\end{array}$ \\
\hline $\begin{array}{l}\text { National Vocational \& } \\
\text { Technical Education }\end{array}$ & \\
\hline Higher Education Commission & \\
\hline
\end{tabular}

\section{Methodology}

The qualitative method was adopted to collect the primary data by conducting interview. Qualitative method is dynamically helpful in that research work which is based on analysis of secondary data and lived experiences, basically this method is helpful to understand a mixture of phenomenon of meaning (Freeman, 2014). Triangulation method is used to check trustworthiness (i.e. Credible, transferable, confirmable and dependable) by collecting data from different sources such as in depth interviews-phenomenology and group discussion-focus group. Triangulation is used to collect the data from different sources to create in depth understanding of phenomenon and avoid any kind of biasness about qualitative research study (Patton, 1999) whereas phenomenology is very helpful in context of philosophy and methodology to understand the complex problems of organization; it is legitimate source to collect the data and participant view in language taken as facts to understand the reality (Goulding, 2005) it is core purpose is to expand and give depth understanding of lived experience (Spiegelberg, 1982) it supports to focus on critical expression on conscious lived experience, it is primarily emphasis to uncover the invariant characteristics of experience (Jopling, 1996); (Bashir, Syed and Qureshi, 2017). The sample size of this study was fifteen (15), which include eight (08) representatives of different departments who were engaged in development and implement the HRD Policy of Pakistan and one focus group interview cum discussion from seven (07) policy experts.

\section{Data Analysis and Findings \\ 4.1. Effective Public Policy}

The state is fully responsible to develop effective public policy and built up environment of trust among individuals, local investors as well as foreign investors and for effective execution of development projects but unfortunately, the Pakistan's government has failed to build up that level of trust among these outfits. Main reason behind this scenario is that the public policy of Pakistan is unrealistic and inconsistent to address the many problems of these outfits. The national policy makers develop different sub public policies in isolation and under the influence of political parties. The HRD Policy of Pakistan is made by policy makers in a way like bits and pieces and there is no one track to reach destination. Therefore, there is no connection of HRD policy with national polices pertain to development or non-development projects. There is no proper road map for development of human resource, like all departments who are working on HRD in Pakistan are constructing its own separate road (Program) and which has no link with any other road, and these different constructed 
roads are not connected with any central road, in addition to this these all roads (programs) are made with low quality of material which can only be survive for only short time.

\subsection{Competency of Policy Makers}

The globalization has entirely changed the pattern of policy making techniques and procedures which were based on orthodox approach. Furthermore, the continuous innovations in computer technology have created tough challenges for policy makers to draw effective public policy which should have consistency with other polices. Pakistan policies makers are using orthodox approach, and they don't have specialized skills, and even don't have accurate data of existing available human resource in the country. Therefore, the policy makers of Pakistan need specialization in different fields which are very important and directly connected in preparation of public policy.

\subsection{Magnitude of HRD Policy in Development}

HRD policy is an important for development of country in every field. Due to globalization and advancement in computer technology have increased it importance as compare to other public policies and it is direct impact on all government vision. Thus, every policy must be hallmarked after the confirmation of development of human capital in specific time for particular project. It required systematic working with specialized skills in different fields, but in Pakistan, the policy makers are not aware the importance of HRD in economic development of country and they continuously ignoring as well as failed to give priority to HRD. Consequently, Policy Makers have allocated very limited budget for the development of human resource which exhibit itself that the lack of understanding the HRD importance in economic development of country. Furthermore, the limited budget which they allocated is only waste of money because the education and skill training programs which they are offering through different organizations or institutions are obsolete and no more use in upcoming days.

\subsection{Research and Development and Database of Human Resource}

Research and Development perform very important role in innovation but in Pakistan Research and Development progress is very limited. Many projects of Pakistan, the government hires human capital of other countries to conduct research in Pakistan, which is very much expensive and infeasible because the expert of other country environment cannot identify the exact problem or solution as compare to expert who lives in Pakistan environment and understand the social and cultural aspects. There is acute shortage of Research and Development in Pakistan. Availability of accurate human resource data (i.e. numbers, type, categories, fields, location and others) is indispensable while making future plans of HRD Policy. In Pakistan, there is no institute or department which can provide this comprehensive information and most of the times, the policy makers of Pakistan just manipulate the data while making HRD Policy.

\subsection{Role of Private Institutions in HRD Policy}

Private institutes of different countries are performing very vital role in human resource development and states governments create positive environment for them to help states in development of human resource to meet requirement of human resource in upcoming projects of the country. In Pakistan, the government doesn't have any proper workout on this aspect in HRD Policy. Overall the results and findings of this study portray that the Pakistan is located in one of the prime location of world and this land has number of natural resources, it has the capacity to compete in world trade war and economic development of this country can be enhanced through review and systematic formulation and implementation of national public policy (it includes all polices) by involving private institutions.

Current ranking position of Pakistan in HRD is in alarming situation and main cause of this is reason is complete failure of existing HRD Policy. The national policy makers of Pakistan are avoiding realities or escaping themselves from the globalization while making public policy for economic development, whereas they clearly mentioned in Vision 2025 that HRD is main pillar of Pakistan Vision- 2025, in which Pakistan will be Asian Tiger up to 2025 and top best economy of world up to 2027. The existing HRD policy of Pakistan is consist of bits and pieces structure; there is no clear road map of one destination. A number of departments are working on human resources development without any clear picture of destination and there is no coherence with each other such as education development programs have no one destination among them, every department have its own programs of education, having its own targets and own way of working patterns which is not linked with education programs of other departments, likewise in Training and skills programs and Research and Development Programs in Pakistan.

\section{Conclusion and Recommondations}

According to public policy of Pakistan Vision-2025, the Pakistan will be the Asian Tiger up to 2025 and Pakistan economy will be counted among top developed economies up to 2047, the main pillar of this policy is human resource development but in reality, the current scenario of economic development of country is opposite to Vision. 
Pakistan's ranking in global human resources development is continuously decreasing; it has reached at number of 125 out of list of 130 countries, which counts in danger zone in context of human resources development. The policy makers of the country are failed to develop effective HRD Policy which is ultimately support to all other public policies in context of Vision- 2025. This Policy is made in bits and pieces which is organizing by various departments, there is no one track to reach destination. Further, it is unrealistic and inconsistent with economic development. There is great need that present government of Pakistan should take this matter seriously and consider following recommendations for the betterment of the country;

1. There is great need to establish a separate ministry for human resources development with having three major portfolios i.e. Research and Development, Education and Trainings and Skill. All portfolios should be further segregate with macro and micro goals. Each goal should be further planned according to short term and long term goals. They should work under one umbrella.

2. Sufficient budget should be allocated for this ministry and hire competent professional (purely on merit basis) in domain for the formulation of effective HRD policy and they should work independently to identify the different programs for HRD according world standard.

3. Proper comprehensive research should be conducted to analysis the availability of human resource in Pakistan such as filed wise, category wise, industry wise, etc. and prepare comprehensive database for this purpose. Further, identify the shortage human resources sketch the HRD program, accordingly. All HRD should be involved based with computer knowledge.

4. All public policies and its projects must be reviewed and rationalized according to facts. No policy should be hallmarked before the concurrence of HRD ministry. According to economic targets of country the HRD ministry must realign it policy with other policies and world best policy standards of human capital development, and set the timeline for the development of requisite human capital in country.

5. There is great need that government should encourage to private institutes through Public Private Partnership for this purpose.

Further, there is great need to work on available human capital in Pakistan and further required in depth study in each component of HRD, such as education, training and skill which definitely help in HRD of Pakistan.

\section{References}

Afza, T. \& Nazir, M. S. (2007). Economic competitiveness and human resource development: An FDI perspective. Pakistan Economic and Social Review, 45(2): 167-180.

Asrar-ul-Haq, M. (2015). Human resource development in Pakistan: Evolution, trends and challenges. Human Resource Development International, 18(1): 97-104.

Bashir, S., Syed, S. \& Qureshi, J. A. (2017). Philosophical and methodological aspects of mixed-methods research: A review of the academic literature. Journal of Independent Studies and Research, 15(1): 3250 .

Clarke, T. \& Gholamshahi, S. (2018). Developing human capital for knowledge based economies. In Innovation in the Asia Pacific. Singapore: Springer. pp: 247-270.

Dunning, J. H. (2006). comment on Dragon multinationals: New players in 21 st century globalization. Asia Pacific Journal of Management- Springer, 23 (2): 139-141.

Freeman, M. (2014). The hermeneutical aesthetics of thick descrition. Qualitative Inquiry (Sage), 20(6): 827833.

Global Human Capital Report, (2016). Economic world forum. pp: 1-39. Available from: https://weforum.ent.box.com/s/dari4dktg4jt2g9xo205pksjpatvawdb.

Global Human Capital Report, (2017). Economic world forum. pp: 1-191. Available from: http://www3.weforum.org/docs/WEF_Global_Human_Capital_Report_2017.pdf.

Goulding, C. (2005). Grounded theory, ethnogrsphy snd phenomenology- a comparative analysis of three qualitative strategies for marketing research. Emerald , 39(3/4).

International Labor Organization, (2016). World employment socail outlook. pp: 1-94. Available from: https://www.ilo.org/global/research/global-reports/weso/2016/WCMS_443480/lang-en/index.htm.

International Institute of Management Development, (1995). Available from: http://iim.org/aboutus/.

Jopling, D. (1996). Sub-phenomenology. Human Studies, 19(2): 153-73.

Latif, A., Nazar, M. S., Khan, T. M. \& Shaikh, F. M. (2011). Human resource development: Strategies for sustainable rural development. Asian Social Science, 7(6): 159-162.

Ministry of Manpower. (2003). Labor market, second quarter 2003 report. Singapore: Author. pp:1-45.

Osman-Gani, A. M. (2004). Human capital development in Singapore: An analysis of national policy perspectives. Advances in Developing Human Resources, 6(3): 276-287.

Patton, M. Q. (1999). Enhancing the quality and credibility of qualitative analysis. Health Services Research, 34(5 Pt 2): 1189-1208.

Porter, R. (1990). What was the enlightenment?. In the enlightenment. London: Palgrave. pp: 1-11. 
Planning Commission, (2005). Planning commission government of Pakistan. pp: 1-68. Available from: https://www.pc.gov.pk/web/downloads.

Planning Commission, (2015). Pakistan vision 2025. Available from: https://www.pc.gov.pk/web/vision.

Reich, Y. (1991). Design knowledge acquisition: Task analysis and a partial implementation. Knowledge Acquisition, 3(3): 237-254.

Skills Development Fund, (2003). Skill development fund, Singapore. Available from: http://www.sdf.gov.sg. [Accessed April 15, 2018].

Spiegelberg, H. (1982). The phenomenological movement. The Hague: Martinus Nijhoff.

Standards, Productivity and Innovation Board, (2003). The former Singapore productivity and standards board. Available from: http://www.spring.gov.sg. [Accessed April 23, 2018].

Tilak, J. B. (2002). Education and poverty. Journal of Human Development, 3(2): 191-207.

Tabassum, S. (2017). State of human resource development (HRD) in Pakistan. International Journal of Science and Research, 6(4): 1060-1064.

Thurow, L. (1994). 3. New game, new rules, new strategies. RSA Journal, 142(5454): 50-56.

United Nations, (1991). Human development report. pp: 1-202. Available from: http://hdr.undp.org/sites/default/files/reports/220/hdr_1991_en_complete_nostats.pdf.

United Nations, (2005). Human resources for effective public administration in a globalized world. Available from: $\quad$ https://publicadministration.un.org/publications/content/PDFs/ELibrary\%20Archives/2005\%20Human\%20Resources\%20for\%20Effective\%20Public\%20Administrati on\%20in\%20a\%20Globalized\%20World.pdf.

Yussof, I. \& Ismail, R. (2002). Human resource competitiveness and inflow of foreign direct investment to the ASEAN region. Asia-Pacific Development Journal, 9(1): 89-107. 